\title{
STABILISASI TANAH MENGGUNAKAN ABU KAYU TERHADAP TANAH LUNAK BENGKALIS
}

\author{
Rio Zambika ${ }^{1 *}$, Ferry Fatnanta ${ }^{2}$, Muhardi ${ }^{3}$ \\ 1,2,3Program Pascasarjana Teknik Sipil, Fakultas Teknik, Universitas Riau \\ Kampus Bina Widya Km 12,5 Simpang Baru Pekanbaru, Provinsi Riau, Indonesia \\ *E-mail: riozambika86@gmail.com, fatnanto1964@gmail.com, amuhardi@gmail.com
}

\begin{abstract}
Abstrak
Tanah lunak dikaitkan dengan tanah yang jika tidak diidentifikasi dan diselidiki dengan cermat dapat menyebabkan masalah ketidakstabilan dan penurunan jangka panjang yang tidak dapat ditoleransi, memiliki kekuatan geser rendah dan kompresibilitas tinggi. Peningkatan jumlah limbah yang tidak diikuti oleh peningkatan dan peningkatan fasilitas dan infrastruktur untuk pengelolaan limbah menyebabkan masalah limbah menjadi lebih serius. Salah satu cara menangani permasalahan tanah lunak adalah dengan cara stabilisasi. Adapun kajian yang akan dilakukan adalah bagaimana pengaruh abu sampah dalam hal ini berupa abu kayu terhadap stabilisasi tanah lunak di pulau Bengkalis dengan kadar campuran abu kayu yang berbeda-beda dan diharapkan dapat meningkatkan kekuatan tanah serta mengurangi dampak permasalahan sampah yang ada. Selain itu juga digunakan bahan lain sebagai pembanding yaitu kapur $(\mathrm{CaO})$ dan kombinasi antara abu kayu dan kapur (CaO). Dari hasil pengujian, kuat tekan bebas (UCS) semakin meningkat seiring bertambahnya waktu pemeraman, namun regangannya berbanding terbalik nilainya semakin kecil, hal ini dikarenakan pada kondisi awal pemeraman, tanah masih dalam kondisi seperti semula dan bersifat lunak, semakin lama tanah akan mengalami pengeringan sedikit demi sedikit dan menjadikan tanah tersebut menjadi lebih getas. Proses perendaman tanah menyebabkan terjadinya penurunan nilai UCS yang besar, makin lama perendaman dilakukan semakin kecil nilai UCSnya. Nilai kuat tekan bebas tanah dipengaruhi oleh proses pencampuran, kadar air, persentase campuran dan lamanya pemeraman (curing).
\end{abstract}

Kata kunci: Stabilisasi, Tanah Lunak, Abu kayu, Kapur, dan Kuat Tekan Bebas

\section{PENDAHULUAN}

Tanah-tanah yang menutupi permukaan bumi terbagi menjadi dua berdasarkan pembentukannya yaitu tanah-tanah residu dan tanah-tanah angkutan. Tanah residu adalah hasil dari pelupakan atau dekomposisi batuan atau tipe tanah lain yang pada prinsipnya tetap berada pada tempatnya pada waktu mereka terbentuk. Jika tanah berpindah ke lokasi yang baru dengan cara pengangkutan bisa disebabkan oleh air yang mengalir, es, gravitasi atau angin disebut sebagai tanah angkutan.

Tanah memiliki sifat yang sangat kompleks, terdiri dari komponen padat yang berinteraksi dengan cairan dan udara. Komponen dalam bentuk tanah dalam bentuk padatan, cairan dan udara jarang dalam kondisi setimbang, selalu berubah mengikuti perubahan yang terjadi pada permukaan tanah yang dipengaruhi oleh suhu udara, angin dan sinar matahari. Kondisi alam di Indonesia yang memiliki musim kemarau dan hujan sehingga berpengaruh pada kekuatan tanah terhadap pembasahan dan pengeringan tanah tersebut.

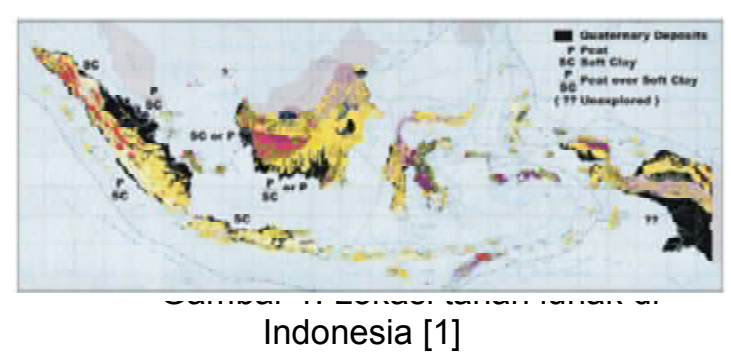

Berdasarkan Gambar 1 di atas, tanah di daerah Riau termasuk dalam tanah angkutan, berada di daerah pesisir dan dataran rendah sehingga sebagian besar daerahnya mempunyai tanah yang lunak dan mempunyai kuat dukung tanah yang rendah, pada umumnya berupa endapan lumpur, lanau, lempung dan gambut

Kabupaten Bengkalis adalah salah satu kabupaten di Provinsi Riau, dengan wilayah 95\% merupakan dataran rendah dengan ratarata ketinggian antara 2-6,1 $\mathrm{m}$ di atas permukaan laut yang di tumbuhi hutan tropis. Pulau bengkalis disebut sebagai delta sungai siak, hal ini karena posisinya tepat berada di muara sungai siak yang mayoritas tanahnya 
adalah jenis tanah lunak.

Tanah lunak memiliki ciri khas sendiri yang jika diselidiki dengan rendahnya kut geser dan tingginya kompresibilitas. membutuhkan ketelitian yang cukup tinggi dan harus secara hati-hati karena bisa menjadi tidak stabil dan bisa terjadi penurunan yang akan sangat berbahaya [1]. Perlu dilakukannya tindakan stablilisasi tanah seperti menambah material tidak aktif serta peningkatan kerapatan tanah agar dapat meningkatkan tahanan gesek ataupun kohesi yang timbul, serta menambahkan bahanbahan yang dapat menyebabkan perubahan fisis maupun kimiawi pada tanah, penggantian tanah yang buruk dan drainase tanah untuk penurunan muka air tanah [2]. Salah satu cara menangani permasalahan tanah lunak adalah dengan cara stabilisasi.

Pertumbuhan populasi dan pola konsumsi masyarakat menghasilkan peningkatan volume, jenis dan karakteristik limbah yang semakin beragam. Peningkatan jumlah limbah yang tidak diikuti oleh peningkatan dan peningkatan fasilitas dan infrastruktur untuk pengelolaan limbah menyebabkan masalah limbah menjadi lebih serius. Paradigma baru pengelolaan sampah yakni memandang sampah sebagai sumber daya yang mempunyai nilai ekonomi dan dapat dimanfaatkan [3]

Dikarenakan banyaknya permasalahan yang ada, baik itu kondisi alam yang berubahrubah di mana berpengaruh pada pembasahan dan pengeringan tanah, permasalahan sampah yang semakin meningkat, kondisi tanah, khususnya di Pulau Bengkalis di mana rata-rata tanahnya adalah tanah lunak yang pada umumnya berupa endapan lumpur, lanau, lempung dan gambut, maka perlu dilakukan kajian terhadap perbaikan tanah yang ada

Adapun kajian yang akan dilakukan adalah bagaimana pengaruh abu sampah dalam hal ini menggunakan abu kayu terhadap stabilisasi tanah lunak di pulau Bengkalis dengan kadar campuran abu kayu yang berbeda-beda dan diharapkan dapat meningkatkan kekuatan tanah serta mengurangi dampak permasalahan sampah yang ada. Selain itu juga digunakan bahan lain sebagai pembanding yaitu kapur $(\mathrm{CaO})$ dan kombinasi antara abu kayu dan kapur $(\mathrm{CaO})$.

Dari penelitian ini, tujuan yang akan dicapai :

1. Mengetahui sifat-sifat fisik tanah pada lokasi penelitian;

2. Mengetahui perilaku pengaruh perbaikan sifat tanah dengan cara stabilisasi baik itu menggunakan campuran abu kayu, kapur maupun kombinasi diantara keduanya dibandingkan dengan sifat-sifat tanah asli dengan kadar campuran yang berbedabeda;

3. Mengetahui pengaruh lama pemeraman dengan suatu proporsi campuran abu kayu, kapur maupun kombinasi di antara keduanya terhadap seberapa jauh daya dukung tanah.

\section{TINJAUAN PUSTAKA}

\section{TANAH}

Tanah merupakan material yang terdiri dari butiran-butiran halus yang tidak tersementasi atau dengan kata lain tidak terikat secara kimia antar satu dengan yang lain dan berasal dari hasil pelapukan organik yang disertai dengan zat-zat cair maupun zat padat yang mengisi ruang yang kosong antara partikel-partikel padat. Pecahan-pecahan yang kecil dan ukurannya di antara batu besar dan partikel tanah berasal dari pelapukan batuan padat yang ukurannya sangat besar [4].

Sistem pengklasifikasian tanah berdasarkan beberapa peraturan dalam menentukan jenis tanah yang ukurannya masing-masing dapat di lihat pada Gambar 2 di bawah ini:

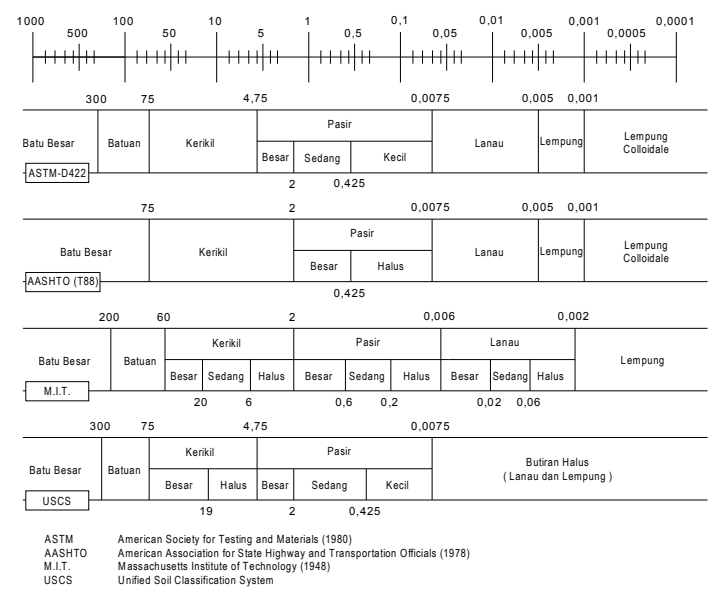

Gambar 2. Batasan-batasan ukuran golongan tanah menurut beberapa sistem pengklasifikasian

Terdapat beberapa sistem klasifikasi tanah yang umum digunakan untuk mengelompokkan tanah. Salah satunya ialah Unified Soil Classification System (USCS). Sistem ini pada mulanya diperkenalkan oleh Casagrande dalam tahun 1942. Sistem memperhitungkan distribusi ukuran butir dan batas Atterberg.

\section{TANAH LUNAK}


Penggunaan istilah "tanah lunak" mengacu pada tanah yang jika tidak diidentifikasi dan diselidiki dengan hati-hati dapat menyebabkan ketidakstabilan jangka panjang dan masalah yang tidak dapat ditoleransi, memiliki kekuatan geser rendah dan kompresibilitas tinggi. Tanah lunak mengandung mineral tanah liat dan mengandung kadar air tinggi. Indonesia tidak dapat dipisahkan dari tanah lunak karena tanah lunak di Indonesia menempati area> 20 juta hektar atau> $10 \%$ dari daratan di Indonesia [1].

Salah satu jenis tanah lunak adalah tanah lempung. Tanah lempung lunak secara umum mempunyai sifat-sifat sebagai berikut:

1) Kuat geser rendah;

2) Berkurang kuat gesernya bila kadar air bertambah dan bila struktur tanahnya terganggu;

3) Bila basah bersifat plastis dan mudah mampat;

4) Menyusut bila kering dan mengembang bila basah;

5) Kompresibilitasnya besar;

6) Berubah volumenya dengan bertambahnya waktu akibat rangkak pada beban yang konstan

\section{Abu Sampah (ABu Kayu)}

Pengertian sampah merupakan material sisa yang tidak diinginkan lagi oleh manusia setelah berakhirnya suatu proses. Dilihat dari komposisi sampahnya, mayoritas sampah kota di Indonesia digolongkan sebagai sampah organik karena kota-kota besar dapat mencapai $70 \%$ dari total sampah, dan sekitar $28 \%$ adalah sampah non-organik yang terdiri dari menjadi objek kegiatan pemulung, mulai dari sumber limbah ke Situs Pembuangan Akhir (TPA). 2\% sisanya diklasifikasikan sebagai hal-hal lain seperti zat berbahaya dan beracun (B3) yang perlu dikelola secara terpisah. [5].

Abu adalah zat anorganik dari pembakaran bahan organik. Abu dapat dilacak karena adanya senyawa yang tidak terbakar yang mengandung unsur-unsur seperti kalsium, kalium, magnesium, mangan, dan silikon.

Abu sampah organik adalah sisa hasil pembakaran dari sampah organik. Sampah organic berasal dari limbah buangan rumah tangga maupun pasar seperti sisa-sisa potongan sayur, daun-daun, buah-buahan dan sebagainya. Sampah organik berasal dari alam dengan bahan penyusun seperti hewan dan tumbuh-tumbuhan yang dihasilkan dari berbagai kegiatan mulai dari rumah tangga, pertanian, peternakan maupun kegiatan yang lain. Sampah ini mudah terurai secara alamiah..

Abu sampah dalam pengujian ini menggunakan abu kayu yang merupakan hasil dari pembakaran sisa limbah kayu dari pabrik meubiler.

\section{KAPUR}

Kapur adalah kalsium oksida $(\mathrm{CaO})$ yang dibuat dari batuan karbonat yang dipanaskan pada suhu sangat tinggi. Kapur tersebut umumnya berasal dari batu kapur (limestone) atau dolomite. Penambahan kapur dalam tanah merubah tekstur tanah. Tanah lempung berubah menjadi berkelakuan mendekati lanau atau pasir, akibat penggumpalan partikel. Pencampuran tanah dengan kapur memperlihatkan pengurangan secara signifikan partikel berukuran lempung $(<0,002 \mathrm{~mm})$ dibandingkan dengan lempung aslinya [6].

Tipe kapur menjadi 4 macam berdasarkan SNI-4147-1996, antara lain :

1. Kapur Tipe I yaitu kapur yang mengandung kalsium hidrat tinggi, dengan kadar magnesium oksida (MgO) paling tinggi $4 \%$;

2. Kapur Tipe II yaitu kapur magnesium atau dolomite yang mengandung magnesium oksida (MgO) dari 4\% dan maksimum 36\% berat;

3. Kapur Tohor $(\mathrm{CaO})$ yaitu hasil pembakaran batu kapur pada suhu + 90oF, dengan komposisi sebagian besar kalsium karbonat $(\mathrm{CaCO} 3)$;

4. Kapur Padam yaitu kapur dari hasil pemadaman kapur tohor dengan air sehingga terbentuk hidrat $\mathrm{Ca}(\mathrm{OH}) 2$.

Kapur tohor $(\mathrm{CaO})$ merupakan bahan yang sangat efektif untuk stabilisasi. Bahan ini dapat digunakan untuk perawatan tanah yang terlalu basah atau kering, tetapi perlu juga diperhatikan penggunaannya dikarenakan dapat menghasilkan panas yang dapat menyebabkan kerugian bahan di sekitarnya.

\section{STABILISASI TANAH}

Secara umum stabilisasi tanah merupakan suatu metode untuk memperbaiki sifat-sifat tanah seperti permeabilitas, kestabilan volume, daya dukung, keawetan dengan memberikan treatment khusus terhadap lapisan tanah seperti dengan menambahkan bahan tambahan guna menjaga kuat geser tanah serta meningkatkan kekuatan tanah. Tujuan dari stabilisasi tanah 
adalah membentuk struktur yang pada pada jalan maupun fondasi dengan mengikat dan menyatukan material-material yang ada.

Stabilisasi tanah adalah suatu metode yang digunakan untuk meningkatkan kemampuan daya dukung suatu lapisan tanah, dengan cara memberikan perlakuan (treatmen) khusus terhadap lapisan tanah tersebut. Hal tersebut dimaksudkan dengan tujuan antara lain :

1. Untuk memperbaiki (meningkatkan) daya dukung tanah;

2. Untuk memperbaiki (memperkecil) penurunan lapisan tanah;

3. Untuk memperbaiki (menurunkan) permeabilitas dan swelling potensial tanah;

4. Untuk menjaga (mempertahankan) potensi tanah yang ada (existing strenght).

Dasar-dasar distribusi ukuran butiran dan batas-batas atterberg digunakan sebagai dasar penelitian macam stabilisasi yang akan digunakan [7]

Tabel 1. Petunjuk awal pemilihan metode stabilisasi

\begin{tabular}{|c|c|c|c|c|c|c|}
\hline $\begin{array}{l}\text { Narerial lolos } \\
\text { sainggn No } 200\end{array}$ & \multicolumn{3}{|c|}{$\begin{array}{l}>25 \% \text { bolor seringn } \\
\text { No } 200(0,075 \mathrm{~ms})\end{array}$} & \multicolumn{3}{|c|}{$\begin{array}{l}<25 \% \text { lobos uringm } \\
\text { No. } 200(0,075=2)\end{array}$} \\
\hline $\begin{array}{c}\text { Indess Plaseses } \\
\mathrm{PI}(/ /)\end{array}$ & $<10$ & $10 \cdot 20$ & $>20$ & $\begin{array}{c}<6(P I x \\
\text { persen } \\
\text { belos } \\
\text { saringn } \\
\text { No } 200<< \\
60)\end{array}$ & $<10$ & $\geq 10$ \\
\hline \multicolumn{7}{|l|}{ Benk: sab:asi } \\
\hline Sesen dencaspran pergilat & Cock & Rags & $\begin{array}{l}\text { Tidat: } \\
\text { Cocok: }\end{array}$ & Cocos: & Coock: & $\operatorname{cosos}$ \\
\hline Kapux & Rage & $\cos \alpha:$ & Cocok: & $\begin{array}{l}\text { Tílok } \\
\text { Cocok: }\end{array}$ & Rage & Cocosk \\
\hline Aspal (Bitruen) & Rage & Ragu & $\begin{array}{l}\text { Tick: } \\
\text { Cock: }\end{array}$ & Cocks & Cock: & Ragi \\
\hline Aspal Semen daspox & $\operatorname{cock}:$ & Rags & $\begin{array}{l}\text { Ticie: } \\
\text { Cocod: }\end{array}$ & Cocok & $\operatorname{coc} \alpha:$ & Ragi \\
\hline Graula & Cock: & $\begin{array}{l}\text { Tidak } \\
\text { cocd: }\end{array}$ & $\begin{array}{l}\text { Tidik } \\
\text { Cocd: }\end{array}$ & Cocok & Cocok: & Ragi \\
\hline Lair-lan campran & $\begin{array}{l}\text { Tidex } \\
\text { Cocoks }\end{array}$ & cock: & Cock: & $\begin{array}{l}\text { Tidati } \\
\text { Cocok }\end{array}$ & Rage & $\operatorname{cosos}$ \\
\hline
\end{tabular}

\section{Pengujian Abu Kayu}

Pengujian ini dilakukan untuk mendapatkan unsur kimia yang terdapat pada abu kayu.

\section{Pengujian Sifat Fisik dan Mekanik TANAH}

Pengujian sifat fisik tanah antara lain :

1. Berat jenis tanah (Gs)
Berat jenis (Gs) didefinisikan sebagai perbandingan antara berat volume partikel padat $\left(\gamma_{\mathrm{s}}\right)$ dengan berat volume air $\left(\gamma_{\mathrm{w}}\right)$ pada suhu standar $20^{\circ} \mathrm{C}$. Pengujian ini bertujuan untuk menentukan berat jenis tanah yang mempunyai butiran tanah lolos saringan No. 200 dengan menggunakan piknometer

2. Atterberg limit

Posisi fisik tanah berbutir halus pada kadar air tertentu disebut konsistensi. Seperti diketahui bahwa konsistensi lempung berubah seiring dengan perubahan kadar air. Tanah lempung akan menjadi lunak bila kadar airnya meningkat dan sebaliknya akan mengeras bila kadar airnya berkurang.

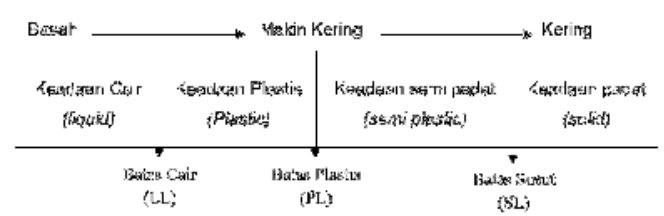

Gambar 3. Tahapan keadaan tanah

3. Gradasi tanah;

Gradasi tanah adalah susunan dari ukuran butir tanah yang membentuk suatu komponen tanah [8]. Ada dua cara untuk menganalisa butiran tanah berdasarkan yaitu [9] :

a. Sieve analysis (analisis saringan atau ayakan)

Digunakan untuk menentukan pembagian ukuran diameter butir tanah yang lebih besar dari $0,075 \mathrm{~mm}$ (No. 200)

b. Hidrometer analysis

Tanah yang butirnya sangat kecil yakni diameternya lebih kecil dari $0,075 \mathrm{~mm}$ (No. 200) tidak efektif lagi disaring dengan saringan yang lebih kecil dari No. 200, bila ingin menentukan besaran butirnya, harus menggunakan analisa hidrometer.

Pengujian sifat mekanik tanah :

1. Proktor

Pengujian proktor bertujuan untuk memperbaiki sifat-sifat teknik tanah dan meningkatkan kekuatan tanah dengan cara dipadatkan sehingga rongga-rongga udara pada sampel tanah asli dapat berkurang yang mengakibatkan kepadatan menjadi meningkat. 
Pengujian pemadatan tanah dilakukan dengan menggunakan metoder pemadatan standar (standard proctor)

\section{UCS (Unconfined Compression Strength Test)}

Kuat kokoh tekan tanah lempung yang tidak terkekang (unconfined, qu) didefinisikan sebagai gaya persatuan luas contoh tanah (spesimen). Kokoh tekan tanah adalah kemampuan contoh tanah untuk menerima tekanan maksimum sebelum spesimen hancur (atau pada regangan aksial maksimum sebesar $20 \%$ ).

Nilai UCS didapat dari pembacaan proving ring dial yang maksimum.

$$
q_{u}=\frac{k \cdot R}{A}
$$

Dimana :

\begin{tabular}{|c|c|}
\hline qu & $=$ Kuat tekan bebas \\
\hline $\mathrm{k}$ & $=$ kalibrasi proving ring \\
\hline $\mathrm{R}$ & = Pembacaan maksimum \\
\hline A & $\begin{aligned}= & \text { Luas penampang contoh } \\
& \text { tanah pada saat pembacaan } \\
& \mathrm{R}\end{aligned}$ \\
\hline
\end{tabular}

\section{METODE PENELITIAN}

\section{Tempat Penelitian}

Penelitian dilakukan di Laboratorium Uji Tanah Politeknik Negeri Bengkalis (Lab. Uji Tanah PNB). Adapun lokasi pengambilan sampel tanah dapat dilihat pada Gambar 4 di bawah ini.

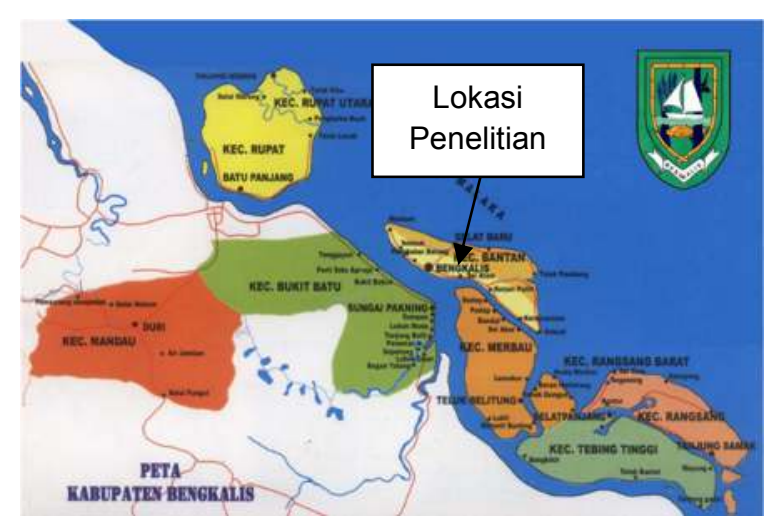

Gambar 4. Lokasi penelitian

\section{BAHAN}

Bahan yang digunakan dalam pengujian sampel tanah adalah sebagai berikut : a. Sampel tanah diambil dari desa Sungai Alam kecamatan Bengkalis Kabupaten Bengkalis Propinsi Riau. Diambil dengan cara dicangkul untuk selanjutnya mengeringkan sampel sampai kondisi kering lapangan;

b. Abu kayu lolos saringan No. 200;

c. Kapur lolos saringan 200;

d. Menggunakan air sumur bor yang berada di laboratorium Uji Tanah Politeknik Negeri Bengkalis.

Tabel 2. Perkiraan jumlah sampel UCS

\begin{tabular}{|c|c|c|c|}
\hline No. & Nama Sampel & Waktu Pemeraman & Keterangan \\
\hline \multirow[t]{4}{*}{1} & \multirow[t]{4}{*}{ Tanah Asli (TA) } & 0 Hari & 3 Sampel \\
\hline & & 7 Hari & 3 Sampel \\
\hline & & 14 Hari & 3 Sampel \\
\hline & & 14 Hari + Rendam & 2 Sampel \\
\hline \multirow[t]{4}{*}{2} & Tanah asli + Abu & 0 Hari & 3 Sampel \\
\hline & Kayu 5\% & 7 Hari & 3 Sampel \\
\hline & \multirow[t]{2}{*}{$(\mathrm{TA}+\mathrm{AK} 5)$} & 14 Hari & 3 Sampel \\
\hline & & 14 Hari + Rendam & 2 Sampel \\
\hline \multirow[t]{4}{*}{3} & Tanah asli + Abu & 0 Hari & 3 Sampel \\
\hline & Kayu $10 \%$ & 7 Hari & 3 Sampel \\
\hline & \multirow[t]{2}{*}{$(T A+A K 10)$} & 14 Hari & 3 Sampel \\
\hline & & 14 Hari + Rendam & 2 Sampel \\
\hline \multirow[t]{4}{*}{4} & Tanah asli + Abu & 0 Hari & 3 Sampel \\
\hline & Kayu $15 \%$ & 7 Hari & 3 Sampel \\
\hline & \multirow[t]{2}{*}{$(T A+A K 15)$} & 14 Hari & 3 Sampel \\
\hline & & 14 Hari + Rendam & 2 Sampel \\
\hline \multirow[t]{4}{*}{5} & \multirow{4}{*}{$\begin{array}{l}\text { Tanah asli + Kapur } \\
5 \% \\
(\mathrm{TA}+\mathrm{KP} 5)\end{array}$} & 0 Hari & 3 Sampel \\
\hline & & 7 Hari & 3 Sampel \\
\hline & & 14 Hari & 3 Sampel \\
\hline & & 14 Hari + Rendam & 2 Sampel \\
\hline \multirow[t]{4}{*}{6} & Tanah asli + Kapur & 0 Hari & 3 Sampel \\
\hline & $10 \%$ & 7 Hari & 3 Sampel \\
\hline & \multirow[t]{2}{*}{$(T A+K P 10)$} & 14 Hari & 3 Sampel \\
\hline & & 14 Hari + Rendam & 2 Sampel \\
\hline \multirow[t]{4}{*}{7} & Tanah asli + Kapur & 0 Hari & 3 Sampel \\
\hline & $15 \%$ & 7 Hari & 3 Sampel \\
\hline & \multirow[t]{2}{*}{$(\mathrm{TA}+\mathrm{KP} 15)$} & 14 Hari & 3 Sampel \\
\hline & & 14 Hari + Rendam & 2 Sampel \\
\hline \multirow[t]{4}{*}{8} & Tanah asli + Kapur & 0 Hari & 3 Sampel \\
\hline & $5 \%+$ Abu kayu $5 \%$ & 7 Hari & 3 Sampel \\
\hline & $(\mathrm{TA}+\mathrm{KP} 5+\mathrm{AK}$ & 14 Hari & 3 Sampel \\
\hline & 5) & 14 Hari + Rendam & 2 Sampel \\
\hline \multirow[t]{4}{*}{9} & Tanah asli + Kapur & 0 Hari & 3 Sampel \\
\hline & $5 \%+$ Abu kayu & 7 Hari & 3 Sampel \\
\hline & $10 \%(\mathrm{TA}+\mathrm{KP} 5+$ & 14 Hari & 3 Sampel \\
\hline & AK 10) & 14 Hari + Rendam & 2 Sampel \\
\hline \multirow[t]{5}{*}{10} & Tanah asli + Kapur & 0 Hari & 3 Sampel \\
\hline & $5 \%+$ Abu kayu & 7 Hari & 3 Sampel \\
\hline & $15 \%(\mathrm{TA}+\mathrm{KP} 5+$ & 14 Hari & 3 Sampel \\
\hline & \multirow[t]{2}{*}{ AK 15) } & 14 Hari + Rendam & 2 Sampel \\
\hline & & Total Sampel & 110 Sampel \\
\hline
\end{tabular}




\section{Tahap Penelitian}

Adapun tahapan penelitian antara lain :

1. Tahapan pembuatan abu kayu

a) Pengumpulan material sampah organik dalam hal ini berupa limbah sisa pabrik meubelair (serbuk kayu)

b) Persiapan tungku pembakaran sampah yang terbuat dari drum dengan kapasitas 200 liter dan diberi pembatas pada bagian bawahnya (sepertiga dari drum) berupa tulangan besi yang diberikan anyaman kawat untuk menampung abu hasil pembakaran, serta di bagian dasar diberikan lubang pernapasan agar pembakaran bisa sempurna;

c) Memasukkan serbuk kayu ke dalam tungku pembakaran dan di padatkan sambil sedikit demi sedikit diberikan air untuk mempermudah proses pemadatan.

d) Proses pembakaran sampah dengan cara membuat lubang di bagian tengah serbuk kayu sehingga mencapai batas tulangan besi agar memudahkan nyala api dalam proses pembakaran.

e) Hasil pembakaran sampah akan dikumpulkan dan dilakukan uji saringan lolos No. 200;

2. Tahapan pengujian di Laboratorium

a) Pengujian analisis kimia abu kayu

Pengujian ini dilakukan untuk mendapatkan unsur kimia yang terdapat pada abu kayu. Pengujian ini dilakukan oleh tim dari Laboratorium Pengujian dan Analisa Kimia Teknik Kimia Fakultas Teknik Universitas Riau. Adapun pengujian yang dilakukan dengan menggunakan metode XRF (X-Ray Fluoroscence) dan AAS (Atomic Absorption Spectrophotometer). XRF yaitu metode analisis dengan menggunakan sinar X sebagai sumber sinarnya. AAS atau spektroskopi serapan ialah suatu metode pengukuran yang didasarkan pada serapan sinar oleh atom.

b) Pengujian sifat fisik dan mekanik tanah

Pengujian ini dilakukan untuk mendapatkan data sifat fisik dan mekanik tanah, sebelum dan sesudah stabilisasi dengan campuran abu kayu, yang meliputi :

1. Pengambilan tanah terganggu;

2. Pengujian Berat jenis;
3. Pengujian Atterberg limit, antara lain pengujian batas cair dan batas plastis;

4. Pengujian Gradasi tanah, menggunakan metode saringan dan hidrometer;

5. Pengujian Pemadatan (Proktor standar), untuk tanah asli, tanah campur abu kayu, tanah campur kapur dan tanah campur kombinasi antara kapur dan abu kayu;

6. Pengujian UCS (Unconfined Compression Stregth), untuk tanah asli, tanah campur abu kayu, tanah campur kapur dan tanah campur kombinasi antara kapur dan abu kayu;

7. Menganalisa hasil pengujian.

\section{Metode Pengujian}

Pengujian Pengujian dilakukan untuk memperoleh data-data mengenai sifat fisis dan mekanis tanah lempung. Dari sifat fisis akan diketahui berat jenis tanah, ukuran butiran tanah dan atterbeg limit tanah lempung. Selain sifat fisis juga akan dilakukan pengujian terhadap sifat mekanis tanah meliputi pengujian proktor dan UCS tanah.

\section{Pengujian Sifat fisiK tanah PENGUJIAN BERAT JENIS}

Pengujian berat jenis tanah dilakukan dengan tujuan adalah untuk mengetahui nilai berat jenis dari tanah lempung. Pengujian dilakukan masing-masing dua kali untuk setiap benda uji, yaitu lolos saringan No. 40 dan No. 200, kemudian dari hasil tersebut dirata-ratakan [10].

\section{PENGUJIAN GRADASI TANAH}

Pengujian gradasi butiran tanah dilakukan untuk menentukan susunan dari ukuran butir tanah yang membentuk komponen tanah. Ada 2 cara pengujian gradasi butiran tanah yaitu, metode saringan dan metode sedimentaasi (hidrometer). Pengujian analisis saringan bertujuan untuk mengetahui persentase ukuran butiran tanah dan susunan butiran tanah (gradasi) dari suatu jenis tanah yang tertahan diatas saringan No. 200, sedangkan pengujian Hidrometer yang bertujuan untuk menentukan pembagian ukuran butir tanah yang lolos saringan No. 200. Hasil dari kedua pengujian akan dimasukkan dalam grafik distribusi gradasi butiran [9]

PENGUJIAN ATTERBERG LIMIT

Atterberg limit adalah batas plastisitas tanah 
yang terdiri dari batas atas kondisi plastis disebut batas plastis (plastic limit) dan batas bawah kondisi plastis disebut batas cair (liquid limit). Adapun pengujian Atterberg limit dilakukan pada kondisi tanah asli, tanah dicampur dengan abu kayu, dengan variasi campuran $5 \%$, $10 \%$ dan $15 \%$, tanah dicampur kapur dengan variasi campuran yang sama serta tanah dicampur kapur dan abu kayu dengan masing-masing komposisi $5 \%+5 \%$, $5 \%+10 \%$ dan $5 \%+15 \%$. Indeks plastisitas (PI) adalah merupakan parameter yang diukur dari selisih antara batas cair tanah (LL) dan batas plastisnya (PL). Semakin besar nilai PI maka semakin besar kemungkinan tanah dalam kondisi plastis [11].

\section{PENGUJIAN SIFAT MEKANIK TANAH PENGUJIAN PROKTOR}

Pada pengujian proktor tanah asli untuk mendapatkan kadar air optimum (optimum moisture content, OMC) dan berat isi kering maksimum (maximum dry density, MDD). Pada mulanya saat kadar air masih $0 \%$ berat volume sama dengan berat volume kering. Jika kadar air ditambah maka berat volume bertambah pula, tapi pada batas tertentu (OMC dan MDD) apabila kadar air ditambah lagi berat volume akan menurun. Hal ini disebabkan apabila sudah padat diberi air lagi partikel tanah akan bergerak dan rongga akan diisi air. Adapun pengujian proktor standar dilakukan pada kondisi tanah asli, tanah dicampur dengan abu kayu, dengan variasi campuran $5 \%, 10 \%$ dan $15 \%$, tanah dicampur kapur dengan variasi campuran yang sama serta tanah dicampur kapur dan abu kayu dengan masing-masing komposisi $5 \%+5 \%$, $5 \%+10 \%$ dan $5 \%+15 \%$ [12].

\section{PENGUJIAN UCS}

Pengujian UCS dilakukan untuk mengetahui kuat geser tanah secara laboratorium. Pada pengujian ini akan diketahui seberapa kuat tanah dengan diberikan beban pada tanah sampai tanah tersebut hancur menjadi butiran-butiran. Pengujian UCS tanah dilakukan terhadap sampel tanah asli, campuran tanah dengan abu kayu, kapur dengan variasi campuran $5 \%$, $10 \%$ dan $15 \%$, serta campuran tanah dengan kapur dan abu kayu dengan masing-masing campuran $5 \%+5 \%, 5 \%+10 \%$ dan $5 \%+15 \%$. Pada masing-masing campuran akan diperam di dalam desikator mulai 0 hari, 7 hari dan 14 hari. Untuk perendaman dilakukan pada umur campuran 14 hari, selanjutnya direndam selama 3 hari (72 jam) [13].

\section{HASIL DAN PEMBAHASAN}

\section{KARAKTERISTIK KIMIA ABU KAYU}

Hasil analisis kimia abu kayu yang diperoleh dari Laboratorium Pengujian dan Analisa Kimia Teknik Kimia Fakultas Teknik Universitas Riau menggunakan Metode XRF (X-Ray Fluoroscence) dan AAS (Atomic Absorption Spectrophotometer) adalah seperti terlihat pada Tabel 3 berikut ini :

Tabel 3. Hasil analisi kimia abu kayu

\begin{tabular}{cccc}
\hline No. & Komposisi & Abu Kayu (\%) & Metode \\
\hline 1 & $\mathrm{MgO}$ & 6,298 & XRF \\
2 & $\mathrm{P}_{2} \mathrm{O}_{5}$ & 4,83 & XRF \\
3 & $\mathrm{Fe}_{2} \mathrm{O}_{3}$ & 0,489 & AAS \\
4 & $\mathrm{CaO}$ & 38,389 & XRF \\
5 & $\mathrm{~K}_{2} \mathrm{O}$ & 9,536 & XRF \\
6 & $\mathrm{SiO}_{2}$ & 36,192 & XRF \\
7 & $\mathrm{SO}_{3}$ & 3,097 & XRF \\
\hline
\end{tabular}

Dari hasil analisi kimia tersebut di atas, dapat disimpulkan bahwa abu kayu didominasi oleh $\mathrm{CaO}$ (kapur) sebesar 38,389\% dan $\mathrm{S}_{\mathrm{i}} \mathrm{O}_{2}$ (silika dioksida) sebesar 36,192\%. Dari Tabel 3 diatas maka abu kayu sangat potensial sebagai bahan stabilisasi tanah.

\section{KARAKTERISTIK FISIK TANAH LEMPUNG}

Pengujian yang dilaksanakan di Laboratorium Uji Tanah Teknik Sipil Politeknik Negeri Bengkalis diperoleh data-data yaitu berat jenis, atterbeg limit (batas cair, batas plastis), analisa saringan. Sampel tanah yang disiapkan adalah tanah lunak dimana tanah tersebut pada kondisi terganggu (disturb). Hasil pengujian karakteristik tanah lempung yang diperoleh dari pengujian di Laboratorium disajikan secara sistematis pada Tabel 4 . Berdasarkan hasil pengujian, nilai batas plastis (PL) tanah asli sebesar 25,7\%, Sedangkan hasil pengujian batas cair (LL) tanah asli adalah 51,25\%. Nilai indeks plastisitas (PI) diperoleh sebesar 25,56\%. Dari ketiga hasil tersebut, apabila dimasukan kedalam Grafik Plastisitas maka tanah asli masuk dalam kategori lempung berplastisitas tinggi $(\mathrm{CH})$. Selain itu didapat nilai berat jenisnya sebesar 2,58 . Berdasarkan Tabel 5 , nilai berat jenis tanah lempung menunjukan bahwa sampel tanah tersebut termasuk dalam golongan tanah lempung organik.

Tabel 4. Hasil pengujian karekateristik fisik tanah lempung 


\begin{tabular}{ccc}
\hline No. & \multicolumn{1}{c}{ Deskripsi } & Nilai \\
\hline 1. & Berat Jenis (Gs) & 2,58 \\
2. & Analisa Saringan & \\
& a. Lolos saringan No. 10 & $99,83 \%$ \\
& b. Lolos saringan No. 40 & $99,68 \%$ \\
& c. Lolos saringan No. 200 & $98,51 \%$
\end{tabular}

3. Batas-batas Atterberg
a. Batas cair (LL)
$51,25 \%$
b. Batas plastis (PL)
$25,70 \%$
c. Indeks plastisitas (PI)
$25,56 \%$

Tabel 5. Klasifikasi berat jenis tanah

\begin{tabular}{lc}
\hline \multicolumn{1}{c}{ Jenis tanah } & Nilai $\mathrm{G}_{\mathrm{s}}$ \\
\hline Kerikil & $2,65-2,68$ \\
Pasir & $2,65-2,68$ \\
Lanau organik & $2,62-2,68$ \\
Lempung organik & $2,58-2,65$ \\
Lempung anorganik & $2,68-2,75$ \\
Humus & 1,37 \\
Gambut & $1,25-1,80$ \\
\hline
\end{tabular}

\section{Pengaruh tANAH + BAHAN StabiLIZER TERHADAP ATTERBERG LIMIT}

Adapun hasil pengujian atterberg limit menggunakan alat casagrande pada sampel tanah asli dicampur dengan bahan stabilizer seperti abu kayu, kapur dna kombinasi diantara keduanya dapat dilihat pada Gambar 5, 6 dan 7 di bawah ini.

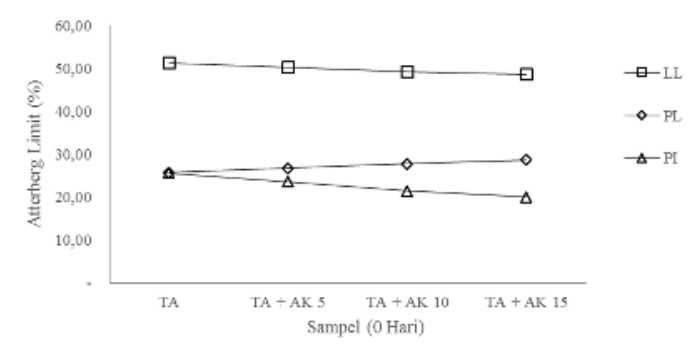

Gambar 5. Pengaruh tanah + abu kayu terhadap atterberg limit

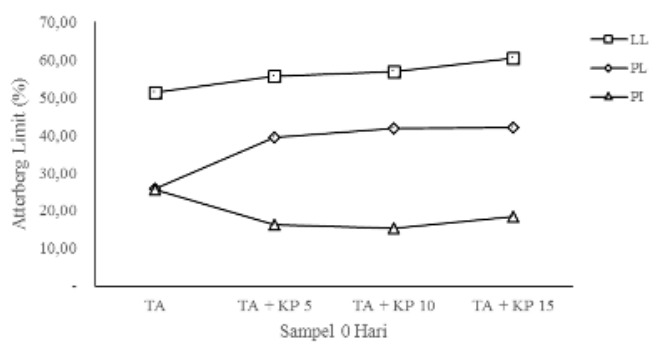

Gambar 6. Pengaruh tanah + kapur terhadap atterberg limit

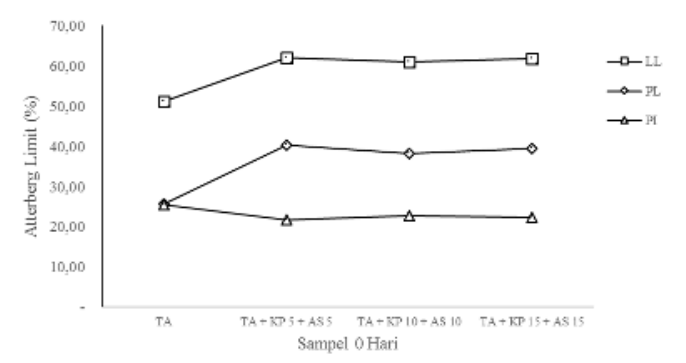

Gambar 7. Pengaruh tanah + kapur + abu kayu terhadap atterberg limit

Hasil pengujian menunjukkan bahwa pencampuran abu kayu, kapur maupun kombinasi diantara keduanya bisa mempengaruhi atterberg limit dari tanah asli. Pada campuran tanah ditambah abu kayu, semakin banyak campuran abu kayu yang digunakan, hasil dari nilai batas cair yang didapat semakin menurun, begitu juga dengan nilai indeks plastisitas. Hal ini berarti bahwa semakin banyaknya kandungan unsur-unsur tersebut yang terdapat pada tanah lempung maka akan semakin banyak pula air yang dibutuhkan untuk merubah dari kondisi semi padat menjadi kondisi plastis. Pada pengujian tanah + kapur, semakin banyak campuran kapur yang digunakan, hasil dari nilai batas cair yang didapat semakin meningkat, berbanding lurus dengan batas plastis, dan terjadi penurunan pada indeks plastisitasnya pada variasi campuran $5 \%$ dan $10 \%$, tetapi terjadi kenaikan pada variasi campuran $15 \%$ walaupun nilai ini masih dibawah PI tanah asli. Dari hasil penelitian tersebut maka dapat disimpulkan bahwa semakin besar kadar kapur untuk stabilisasi tanah maka semakin kecil nilai indeks plastisitasnya, sehingga dapat diartikan dengan penambahan kapur maka akan menjadikan tanah lempung lebih stabil, sampai batas tertentu. Sedangkan untuk kombinasi diantara keduanya, Secara garis besar terjadinya penurunan indeks plastisitas dari tanah asli terhadap campuran kapur ditambah abu kayu, walaupun nilai penurunannya tidak terlalu besar. Setiap 
pengujian dapat menghasilkan nilai yang berbeda walaupun sampel uji pada kondisi yang sama.

Gambar 8 di bawah ini menunjukkan adanya hubungan antara indeks plastistas tanah terhadap penggunaan abu kayu dan kapur maupun kombinasi diantara keduanya dapat mempengaruhi klasifikasi dari jenis tanah tersebut.

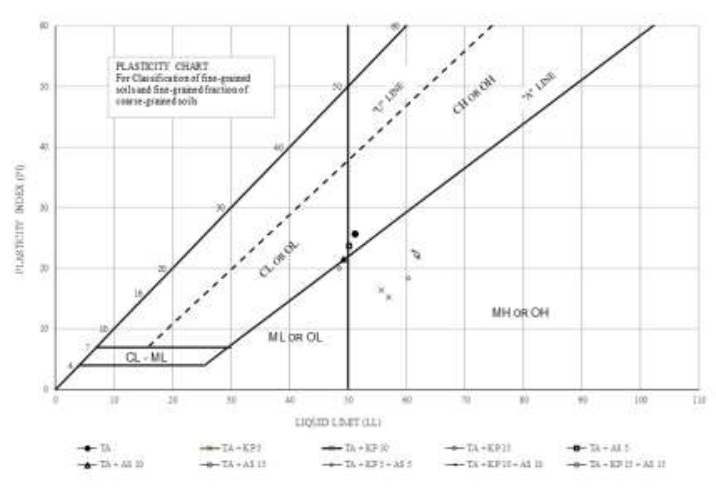

Gambar 8. Klasifikasi tanah berdasarkan USCS

Sampel tanah yang diambil dari sekitar Desa Sungai Alam Kecamatan Bengkalis Kabupaten Bengkalis menurut klasifikasi Sistem Unified (USCS) termasuk dalam tanah berbutir halus kelompok $\mathrm{CH}$ yaitu lempung organik dengan plastisitas tinggi.

Sesuai dengan Gambar 8 di atas tentang klasifikasi tanah berdasarkan USCS, dapat dikatakan bahwa secara garis besar, setiap penambahan abu kayu, kapur maupun kombinasi diantara keduanya, pergerakan jenis tanah cenderung berada dibawah garis $A$ dan masuk dalam klasifikasi tanah lanau.

\section{KARAKTERISTIK MEKANIK TANAH LEMPUNG}

\section{Pengujian Pemadatan tanah} (PROKTOR STANDAR)

Pada pengujian proktor tanah asli untuk mendapatkan kadar air optimum (optimum moisture content, OMC) dan berat isi kering maksimum (maximum dry density, MDD). Pada saat pemadatan, air berfungsi sebagai pelunak (softening agent). Pada mulanya saat kadar air masih $0 \%$ berat volume sama dengan berat volume kering. Jika kadar air ditambah maka berat volume bertambah pula, tapi pada batas tertentu, apabila kadar air ditambah lagi berat volume akan menurun. Hal ini disebabkan apabila sudah padat diberi air lagi partikel tanah akan bergerak dan rongga akan diisi air. Hasil pengujian diperlihatkan pada Gambar 9 dibawah ini.

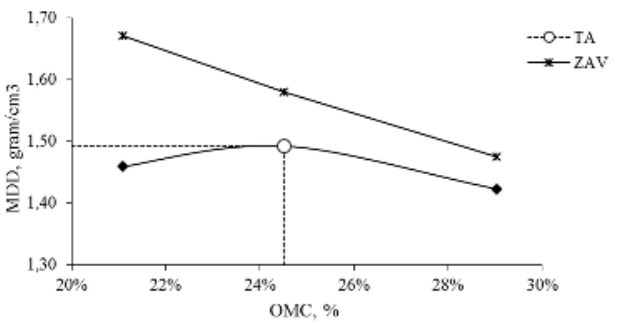

Gambar 9. Grafik proktor pada tanah asli

Dari gambar 4.7 dapat dilihat nilai kadar air optimum (optimum moisture content, OMC) pada tanah asli adalah $24,51 \%$ dengan berat volume kering (maximum dry density, MDD) $1,49 \mathrm{gr} / \mathrm{cm} 3$. Semakin tinggi penambahan jumlah kadar air, maka berat kering tanah akan berkurang karena penambahan air tersebut akan memperkecil konsentrasi partikel-partikel tanah persatuan volume [4].

\section{HUBUNGAN TANAH + BAHAN STABILIZER TERHADAP MDD DAN OMC}

Adapun hasil pengujian proktor standar pada sampel tanah asli dicampur dengan abu kayu dapat dilihat pada Gambar 10, 11 dan 12 di bawah ini.

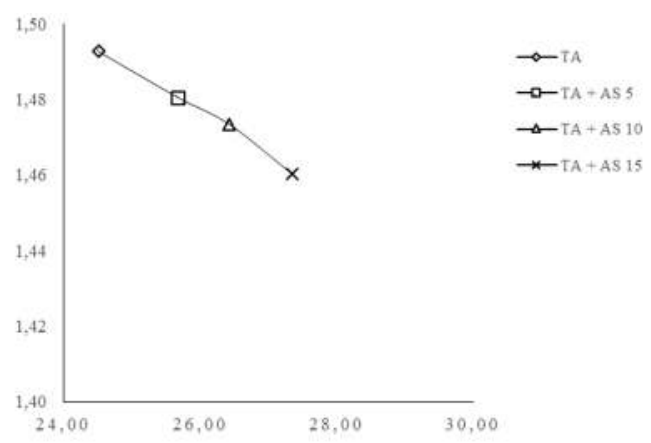

Gambar 10. Hubungan tanah + abu kayu terhadap MDD dan OMC

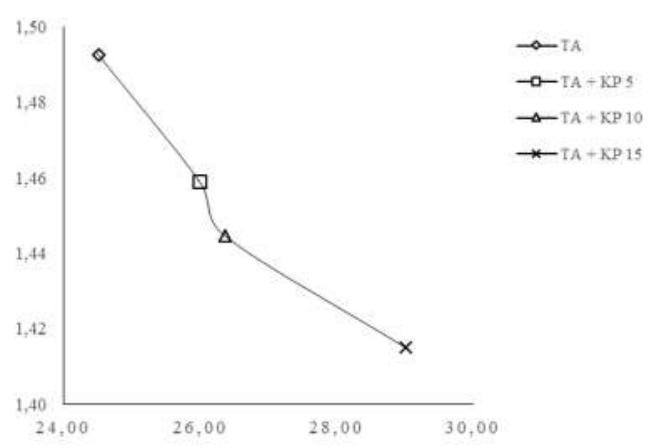

Gambar 11. Hubungan tanah + kapur terhadap MDD dan OMC 


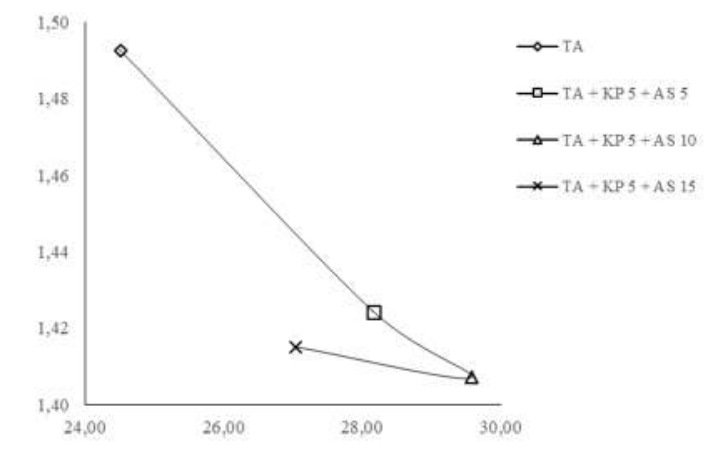

Gambar 12. Hubungan tanah + kapur + abu kayu terhadap MDD dan OMC

Dari hasil pengujian proktor tanah asli dicampur abu kayu dapat dilakukan analisa sebagai berikut. Nilai OMC pada penambahan abu kayu cenderung mengalami peningkatan, berbanding terbalik dengan nilai MDDnya.

Pengujian proktor tanah asli dicampur kapur dapat dapat mempengaruhi Nilai OMC dan MDD tanah asli, berperilaku sama seperti pada penambahan abu kayu, tetapi lebih menjadikan nilai MDD besar penurunan nilainya. Hal tersebut seperti terlihat pada Gambar 10 di samping. Campuran tanah kapur yang dipadatkan pada usaha pemadatan tertentu, akan mempunyai berat volume kering maksimum (MDD) yang lebih rendah dibandingkan dengan tanah asli tanpa kapur. Selain itu, kadar air optimum (OMC) juga bertambah dengan naiknya kadar kapur [6].

Nilai OMC pada penambahan kapur dan abu kayu cenderung mengalami peningkatan, pada campuran $5 \%-10 \%$ abu kayu dan turun pada campuran $15 \%$ abu kayu, tetapi masih berada diatas OMC tanah asli. Begitu juga dengan nilai MDDnya, mengalami penurunan sama seperti pada penambahan abu kayu dan kapur.

\section{PenguJian UCS (UnCONFINED COMPRESSION STRENGTH TES)}

Pengujian UCS dilakukan untuk mengetahu seberaa besar kuat geser tanah di laboratorium. Pengujian ini beban pada tanah sampai tanah menjadi hancur seperti butiranbutiran dan juga untuk mengetahui regangan pada tanah akibat dari tekanan tersebut. Pengujian dilakukan di Laboratorium Uji Tanah Politeknik Negeri Bengkalis. Nilai UCS didapat dari pembacaan proving ring dial yang maksimum. Pengujian UCS tanah dilakukan terhadap sampel tanah asli, campuran tanah dengan abu kayu dengan kadar 5\%, 10\% dan $15 \%$, campuran tanah dengan kapur dengan kadar yang sama serta campuran tanah dengan kapur dan abu kayu dengan masingmasing komposisi 5\%+5\%, 5\%+10\% dan $5 \%+15 \%$. Kadar air optimum sebesar $24,5 \%$ kemudian diperam di dalam desikator dengan menjaga kelembabannya selama 0 hari, 7 hari dan 14 hari. Proses perendaman dilakukan untuk umur campuran 14 hari, selanjutnya direndam selama 3 hari dengan asumsi air meresap secara merata keseluruh permukaan sampel.

Nilai UCS akan dianalisa faktor-faktor yang mempengaruhinya baik itu dikarenakan campuran abu kayu, kapur maupun kombinasi diantara keduanya, lamanya pemeraman maupun dikarenakan proses perendaman.

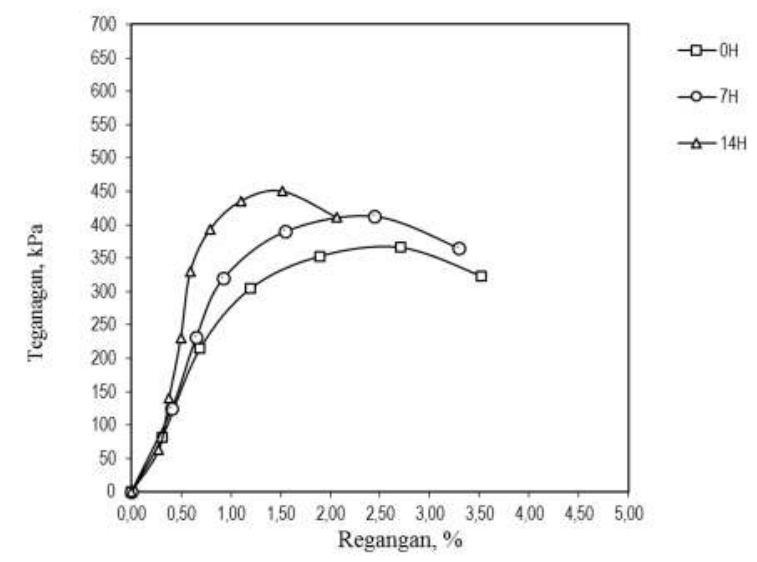

Gambar 13. Hasil pengujian UCS tanah asli

Gambar 13 memperlihatkan tegangan dan regangan yang didapatkan dari hasil pengujian UCS untuk tanah asli pada pemeraman 0 hari, 7 hari dan 14 hari. Nilai UCS semakin meningkat seiring bertambahnya waktu pemeraman, namun regangannya berbanding terbalik nilainya semakin kecil, hal ini dikarenakan pada kondisi awal pemeraman, tanah asli masih dalam kondisi seperti semula dan bersifat lunak, semakin lama tanah akan mengalami pengeringan sedikit demi sedikit dan menjadikan tanah tersebut menjadi lebih getas. Hal ini dipengaruhi kadar air, semakin banyak kadar air yang terdapat dalam tanah maka regangannya akan semakin besar.

\section{Hubungan Nilai UCS dan WaKtu Pemeraman Pada Tanah Asl}

Hasil pengujian UCS dilakukan terhadap waktu pemeraman menunjukkan semakin lama tanah diperam maka akan meningkatkan nilai UCSnya. Hal ini dapat dilihat pada 
Gambar 14. Dari hasil pengujian UCS didapat nilai Tegangan (qu) tanah asli dengan perawatan 0 hari sebesar $366,10 \mathrm{kPa}$ dan terus mengalami peningkatan seiring penambahan waktu masa perawatan yaitu nilai qu untuk masa perawatan 7 hari 412,70 $\mathrm{kPa}$ dan 450,44 $\mathrm{kPa}$ untuk nilai qu masa perawatan 14 hari. Hal ini dikarenakan pada masa 0 hari, kadar air tanah masih belum mengalami perubahan dan mempunyai elastisitas yang masih tinggi, dan seiring waktu berjalan kadar air tanah akan berkurang sehingga tanah akan bersifat lebih getas yang mengakibatkan kehancuran lebih segera, tetapi meningkatkan nilai UCS tanah.

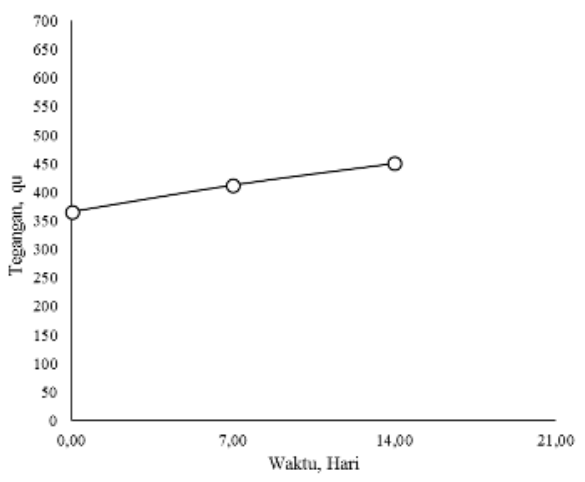

Gambar 14. Hubungan nilai UCS dan waktu pemeraman pada tanah asli

\section{HUBUNGAN TANAH + BAHAN STABILIZER TERHADAP UCS DAN WAKTU PEMERAMAN}

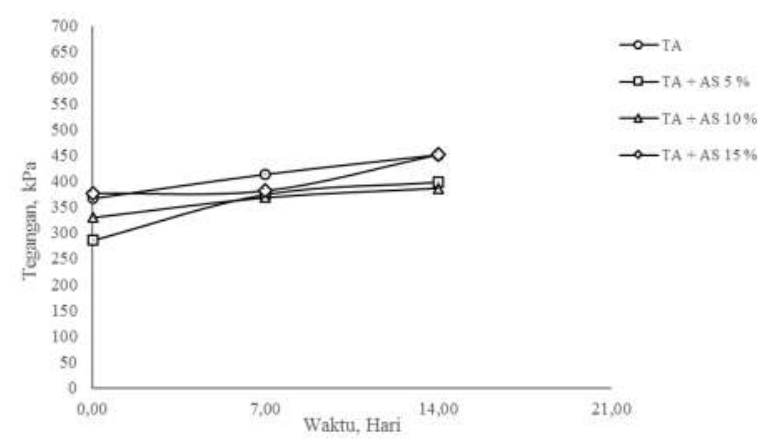

Gambar 15. Hubungan Tanah + Abu kayu terhadap nilai UCS dan waktu pemeraman

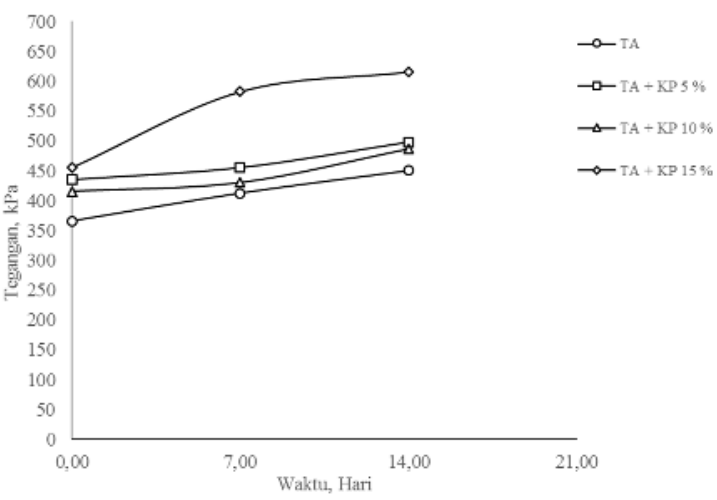

Gambar 16. Hubungan Tanah + Kapur terhadap nilai UCS dan waktu pemeraman

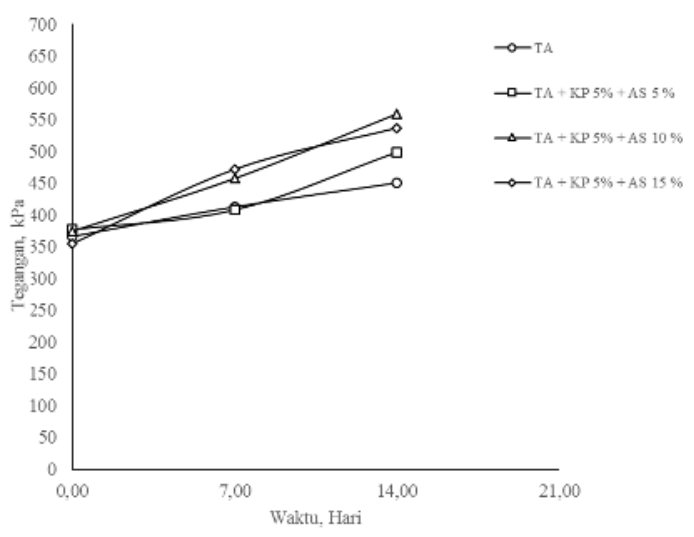

Gambar 17. Hubungan Tanah +Kaput + Abu kayu terhadap nilai UCS dan waktu pemeraman

Gambar 15 menunjukan hasil pengujian UCS untuk tanah dicampur abu kayu dengan variasi waktu pemeraman selama 0 hari, 7 hari dan 14 hari. Hasil pengujian memperlihatkan terjadi kenaikan dan penurunan nilai tegangan (qu) tanah, tetapi kenaikan dan penurunannya masih berada dibawah tanah asli.

Kenaikan nilai UCS cepat terjadi pada campuran tanah asli dan kapur, segera setelah pencampuran tanah dengan kapur oleh adanya reaksi cepat pertukaran kation, penggumpalan dan penggumpalan butir tanah menjadi lebih besar. Selain itu juga dikarenakan adanya reaksi pozzolanik yang semakin lama akan memperbesar nilai UCS tanah. Gambar 16 memperlihatkan terjadinya kenaikan nilai UCS tanah campur kapur dan semuanya berada diatas nilai UCS tanah asli.

Pengujian UCS untuk tanah dicampur variasi campuran kapur dan abu kayu yang berbeda-beda untuk campuran $5 \%, 10 \%$, dan $15 \%$ seperti terlihat pada Gambar 17. nilai UCS cenderung meningkat. Peningkatan yang stabil terjadi pada kondisi campuran abu kayu 
$10 \%$, dimana dapat dilihat pada gambar di atas kurvanya membentuk garis lurus.

\section{Hubungan Tegangan dan Kadar AIR (OMC) PADA TANAH ASLI}

Hubungan antara tegangan dan kadar air (OMC) dapat di lihat dari hasil pengujian UCS seperti pada Gambar 18. Hal ini memperlihatkan adanya pengaruh kadar air terhadap nilai UCS tanah, dimana semakin besar kadar air tanah akan menyebabkan nilai UCS tanah menurun. Pada kadar air $23,18 \%$, nilai UCSnya $366,10 \mathrm{kPa}$, kadar air akan turun pada umur 7 hari menjadi $22,28 \%$ dan UCS tanahnya sebesar $412,70 \mathrm{kPa}$, begitu juga pada masa pemeraman 14 hari terjadi kenaikan nilai UCS tanah 450,44 $\mathrm{kPa}$ dan penurunan kadar air menjadi sebesar $21,16 \%$.

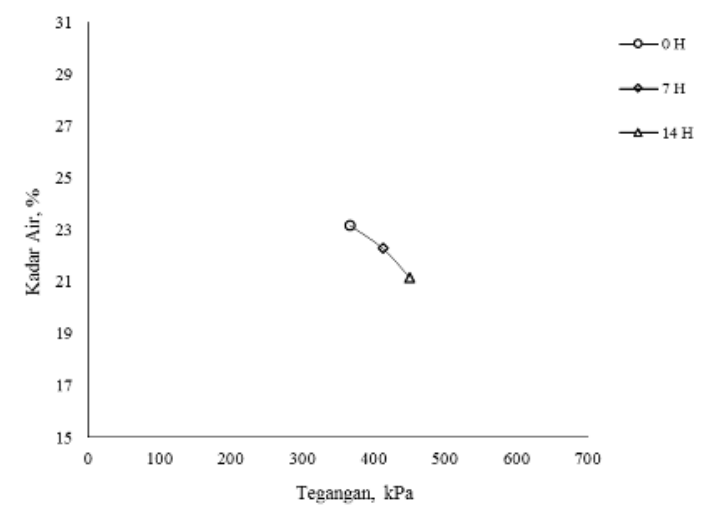

Gambar 18. Hubungan tegangan dan kadar air

\section{Hubungan UCS TeRhadap Perendaman PADA TANAH ASLI}

Berdasarkan hasil pengujian UCS pada tanah asli yang sebelumnya di rendam selama 72 jam dengan asumsi air sudah terserap ke dalam tanah terlihat pada gambar di bawah ini.

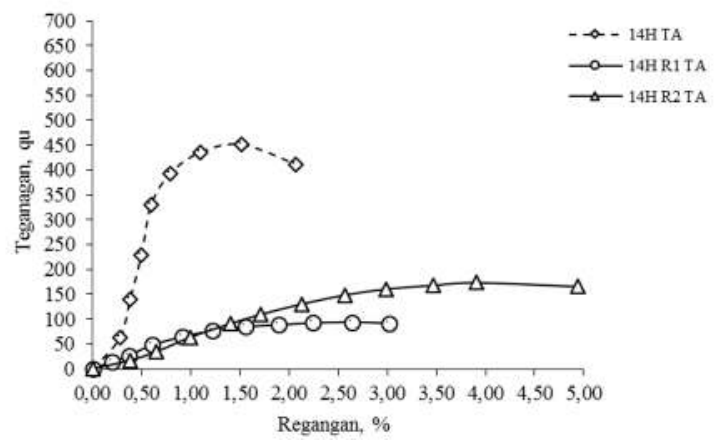

Gambar 19. Hubungan UCS tanah asli terhadap perendaman

Nilai kuat tekan bebas (UCS) tanah lempung mengalami penurunan yang drastis akibat perendaman tanah selama 72 jam. Pengaruh rendaman akan mereduksi kekuatan UCS tanah, hal ini disebabkan meningkatnya kadar air tanah yang semula $21,16 \%$ menjadi $29,06 \%$ dan setelah dianginkan selama 1 jam berkurang akibat udara sebesar 27,63\% sehingga menyebabkan kondisi tanah menjadi lebih plastis. UCS tanah berkurang sebesar $79,14 \%$ dari 450,44 $\mathrm{kPa}$ menjadi 93,96 kPa, tetapi meningkat lagi setelah dianginkan selama 1 jam menjadi $173,11 \mathrm{kPa}$. Nilai regangan meningkat dikarenakan kadar air tanah meningkat sehingga meningkatkan elastisitas tanahnya sehingga tidak mudah hancur. Pada kondisi OMC nilai regangan tanah sebesar $0,79 \%$ meningkat menjadi $2,64 \%$.

\section{KESIMPULAN}

Dari hasil analisi kimia abu sampah yang pengujiannya dilakukan di Laboratorium Pengujian dan Analisa Kimia Teknik Fakultas Teknik Universitas Riau, dapat disimpulkan bahwa abu kayu didominasi oleh $\mathrm{SiO}_{2}$ (Silika Dioksida) sebesar 36,192\% dan $\mathrm{CaO}$ (kapur) sebesar 38,389\%. Tanah lempung yang digunakan sebagai sampel penelitian berasal dari Desa Sungai Alam Kecamatan Bengkalis Kabupaten Bengkalis termasuk dalam kategori tanah lempung lunak plastisitas tinggi dengan nilai PI nya sebesar 25,56\%. Berdasarkan klasifikasi menurut USCS (Unified Soil Clasification System) tanah ini termasuk kedalam kelompok $\mathrm{CH}$.

Abu kayu, kapur dan kombinasi antara kapur dan abu kayu dapat menurunkan nilai PI tanah lempung. Semakin besar campuran yang digunakan terhadap tanah, maka akan nilai PInya akan semakin menurun dari nilai PI tanah lempung. Hal ini berarti bahwa semakin banyaknya kandungan unsur-unsur tersebut yang terdapat pada tanah lempung maka akan semakin banyak pula air uang dibutuhkan untuk merubah dari kondisi semi padat menjadi kondisi plastis. Dari hasil pengujian proktor standar didapat nilai kadar air optimum (optimum moisture content, OMC) tanah sebesar $24,51 \%$ dengan berat volume kering (maximum dry densyity, MDD) 1,49 gr/cm3. 6 . Nilai OMC pada penambahan abu kayu cenderung mengalami peningkatan, berbanding terbalik dengan nilai MDDnya, Hal ini disebabkan karena abu kayu menyerap air dan menyebabkan kadar air menjadi meningkat dan tanah menjadi lebih ringan. Pengujian proktor tanah asli dicampur kapur dapat dapat mempengaruhi Nilai OMC dan MDD tanah asli, berperilaku sama seperti pada penambahan abu kayu, tetapi lebih 
Rio Zambika ${ }^{1 *}$, Ferry Fatnanta ${ }^{2}$, dan Muhardi ${ }^{3}$

menjadikan nilai MDD besar penurunan nilainnya. Hal ini disebabkan karena kapur lebih cepat menyerap air dan menyebabkan kadar air menjadi meningkat dan tanah menjadi lebih ringan. Nilai OMC pada penambahan kapur dan abu kayu cenderung mengalami peningkatan, pada campuran $5 \%$ $10 \%$ abu kayu dan turun pada campuran $15 \%$ abu kayu, tetapi masih berada diatas OMC tanah asli. Begitu juga dengan nilai MDDnya, mengalami penurunan sama seperti pada penambahan abu kayu dan kapur.

Dari hasil pengujian kuat tekan bebas (UCS) yang dilakukan di laboratorium Politeknik Negeri Bengkalis, Nilai UCS semakin meningkat seiring bertambahnya waktu pemeraman, namun regangannya berbanding terbalik nilainya semakin kecil, hal ini dikarenakan pada kondisi awal pemeraman, tanah asli masih dalam kondisi seperti semula dan bersifat lunak, semakin lama tanah akan mengalami pengeringan sedikit demi sedikit dan menjadikan tanah tersebut menjadi lebih getas. Hal ini dipengaruhi kadar air, semakin banyak kadar air yang terdapat dalam tanah maka reganganya akan semakin besar.

Penggunaan abu kayu untuk stabilisasi tanah tidak dapat meningkatkan nilai UCS malah membuat semakin menurun. Kapur menunjukkan peningkatan nilai UCS yang besar, hal ini sesuai dengan penelitianpenelitian sebelumnya. Hasil dari pengujian UCS dengan penambahan kombinasi antara kapur dan abu kayu menunjukkan hasil yang positif, dapat menutupi kekurangan yang ada pada abu kayu dan kapur dari segi kegetasan tanah.

Dari hasil pengujian UCS yang dilakukan di Laboratorim, semakin lama waktu pemeraman yang dilakukan semakin tinggi pula nila UCSnya.

\section{DAFTAR PUSTAKA}

[1] Pedoman Kimpraswil, 2002, Panduan Geoteknik 1 (Proses Pembentukan dan SifatSifat Dasar Tanah Lunak), Departemen Permukiman dan Prasarana Wilayah, Jakarta.

[2] Bowles, J.E., 1991, Sifat-sifat Fisis dan Geoteknis Tanah, Erlangga, Jakarta.

[3] Republik Indonesia. 2008, Undang-Undang No. 18 Tahun 2008 tentang Pengelolaan Sampah, Jakarta.

[4] Braja M. Das., 1993. Mekanika Tanah (Prinsip - prinsip Rekayasa Geoteknis), Jilid I, Erlangga, Jakarta.
[5] Safrizal., 2014, Distributed Generation Pembangkit Listrik Tenaga Sampah Kota (PLTs) Type Incinerator Solusi Listrik Alternatif Kota Medan, dalam Prosiding SNATIF Ke-1 Tahun 2014, Fakultas Teknik Universitas Muria Kudus, Jawa Tengah.

[6] Hary Christady Hardiyatmo, 2010, Stabilisasi Tanah (Untuk Perkerasan Jalan), Gadjah Mada University Press, Yogyakarta.

[7] Hicks, R.G., 2002, Alaska Soil Stabilization Design Guide, Departemen of Transportation and Public Facilities

[8] Hary Christady Hardiyatmo, 2002, Mekanika Tanah I, Gadjah Mada University Press, Yogyakarta.

[9] SNI 3423 : 2008, Cara Uji Analisis Ukuran Butiran Tanah, Badan Standarisasi Nasional, Jakarta.

[10] SNI 1964 : 2008, Cara Uji Berat Jenis Tanah, Badan Standarisasi Nasional, Jakarta.

[11] SNI 1966 : 2008, Cara Uji Penenetuan Batas Plastis dan Indeks Plastisitas Tanah, Badan Standarisasi Nasional, Jakarta.

[12] SNI 1742 : 2008, Cara Uji Kepadatan Ringan Untuk Tanah, Badan Standarisasi Nasional, Jakarta.

[13] SNI 3638 : 2012, Metode Uji Kuat Tekan Bebas Tanah Kohesif, Badan Standarisasi Nasional, Jakarta. 